\title{
Excreted Steroids in Vertebrate Social Communication
}

\author{
Wayne I. Doyle and ๑Julian P. Meeks \\ University of Texas Southwestern Medical Center, Dallas, Texas 75390-9111
}

\begin{abstract}
Steroids play vital roles in animal physiology across species, and the production of specific steroids is associated with particular internal biological functions. The internal functions of steroids are, in most cases, quite clear. However, an important feature of many steroids (their chemical stability) allows these molecules to play secondary, external roles as chemical messengers after their excretion via urine, feces, or other shed substances. The presence of steroids in animal excretions has long been appreciated, but their capacity to serve as chemosignals has not received as much attention. In theory, the blend of steroids excreted by an animal contains a readout of its own biological state. Initial mechanistic evidence for external steroid chemosensation arose from studies of many species of fish. In sea lampreys and ray-finned fishes, bile salts were identified as potent olfactory cues and later found to serve as pheromones. Recently, we and others have discovered that neurons in amphibian and mammalian olfactory systems are also highly sensitive to excreted glucocorticoids, sex steroids, and bile acids, and some of these molecules have been confirmed as mammalian pheromones. Steroid chemosensation in olfactory systems, unlike steroid detection in most tissues, is performed by plasma membrane receptors, but the details remain largely unclear. In this review, we present a broad view of steroid detection by vertebrate olfactory systems, focusing on recent research in fishes, amphibians, and mammals. We review confirmed and hypothesized mechanisms of steroid chemosensation in each group and discuss potential impacts on vertebrate social communication.
\end{abstract}

Key words: vertebrate; olfaction; chemosensation; steroid; bile acid; pheromone

\section{Introduction}

Olfactory pathways have evolved to interpret environmental cues that support survival and reproduction. Most vertebrates possess multiple olfactory systems that allow them to detect and interpret social chemosignals. These parallel olfactory systems support a wide range of important behaviors, including mating, aggression, and predator avoidance (Belanger and Corkum, 2009; Houck, 2009; Bazáes et al., 2013; Stowers and Kuo, 2015). Throughout vertebrate evolution, the ability to detect certain informative chemical classes (e.g., biogenic amines) has been conserved (Liberles and Buck, 2006; Liberles, 2009; Ferrero et al., 2011; Zhang et al., 2013). Steroids (sex steroids, glucocorticoids, neurosteroids, and bile acids) are increasingly being recognized for their capacity to serve as activating ligands for vertebrate olfactory neurons (W. Li et al., 1995; Friedrich and Korsching, 1998; Nodari et al., 2008; Isogai et al., 2011; Haga-Yamanaka et al., 2014; Doyle et al., 2016; Greer et al., 2016). Nuclear receptors (for review, see Evans and Mangelsdorf, 2014) and several steroid-sensitive plasma membrane receptors (Kawamata et al., 2003 for review, see Wang et al., 2014) are known to play important roles in mammalian physiology. However, evidence suggests that it is not these receptors, but

Received Oct. 19, 2017; revised Jan. 22, 2018; accepted March 3, 2018.

This work was supported by National Institute on Deafness and Other Communication Disorders Grant R01DC015784 to J.P.M. and National Institute of General Medical Sciences Grant T32GM0007062 to W.I.D. This work was supported in part by Welch Foundation Grant 1-1934-20170325. The content is solely the responsibility of the authors and does not necessarily represent the official views of the National Institutes of Health. We thank Dean Smith, David Mangelsdorf, and David Russell for helpful suggestions on the manuscript.

The authors declare no competing financial interests.

Correspondence should be addressed to Dr. Julian P. Meeks, 5323 Harry Hines Blvd, Dallas, TX 75390-9111. E-mail: julian.meeks@utsouthwestern.edu.

DOI:10.1523/JNEUROSCI.2488-17.2018

Copyright $\odot 2018$ the authors $\quad 0270-6474 / 18 / 383377-11 \$ 15.00 / 0$ chemosensory GPCRs and 4-transmembrane domain receptors that sense environmental steroids (Isogai et al., 2011; HagaYamanaka et al., 2014; Greer et al., 2016). Steroids have the potential to convey information about reproductive status and health, and accordingly some, but not all, steroid ligands have been linked to social and reproductive behaviors (Hurk and Lambert, 1983; Stacey and Sorensen, 1986; Sorensen et al., 1995; Poling et al., 2001; W. Li et al., 2002; Haga-Yamanaka et al., 2014; Fu et al., 2015). Steroids are not the only hormones that also serve as external chemosignals (Yabuki et al., 2016); but in the interest of clarity, we focus exclusively on steroid chemosignals in this manuscript. The topics of olfactory receptor evolution (Fleischer et al., 2009; Korsching, 2009; Niimura, 2009), olfactory system organization and function (Houck, 2009; Bazáes et al., 2013; Buchinger et al., 2015; Stowers and Kuo, 2015), and steroid synthesis and metabolism (Miller and Auchus, 2011; Evans and Mangelsdorf, 2014; Copple and Li, 2016) have all been recently covered, and we refer readers interested in each of these topics to the relevant reviews. Reptiles also possess chemosensory systems capable of detecting steroids (Houck, 2009) but are not discussed here. In this Viewpoints article, we begin by briefly reviewing chemical features of steroids and then discuss steroid chemosensory research in fishes, amphibians, and mammals. We conclude by mentioning areas we believe are ripe for discovery, and discussing potential implications of olfactory steroid sensing for vertebrate behavior.

\section{Steroids are a structurally diverse, information-rich family of molecules}

Steroids perform diverse functions in the body; and as derivatives of cholesterol, they share common structural features. Steroids contain a core of four fused rings that can take on a flat (cis-or $\alpha$ ) 
a

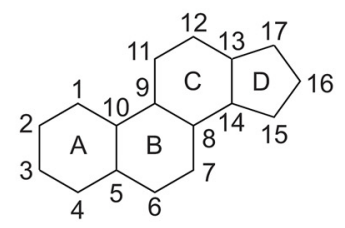

b

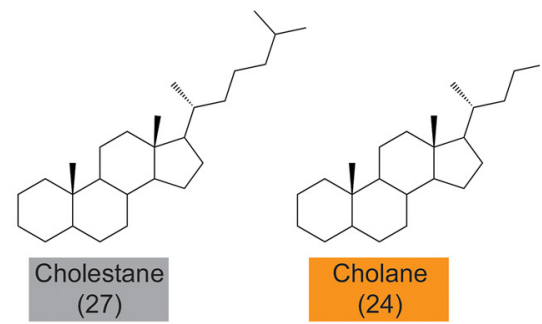

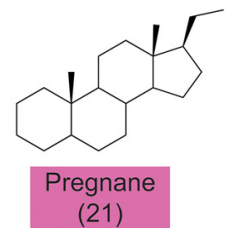
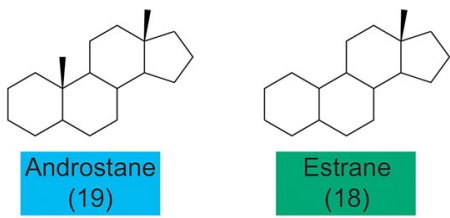

\section{C}

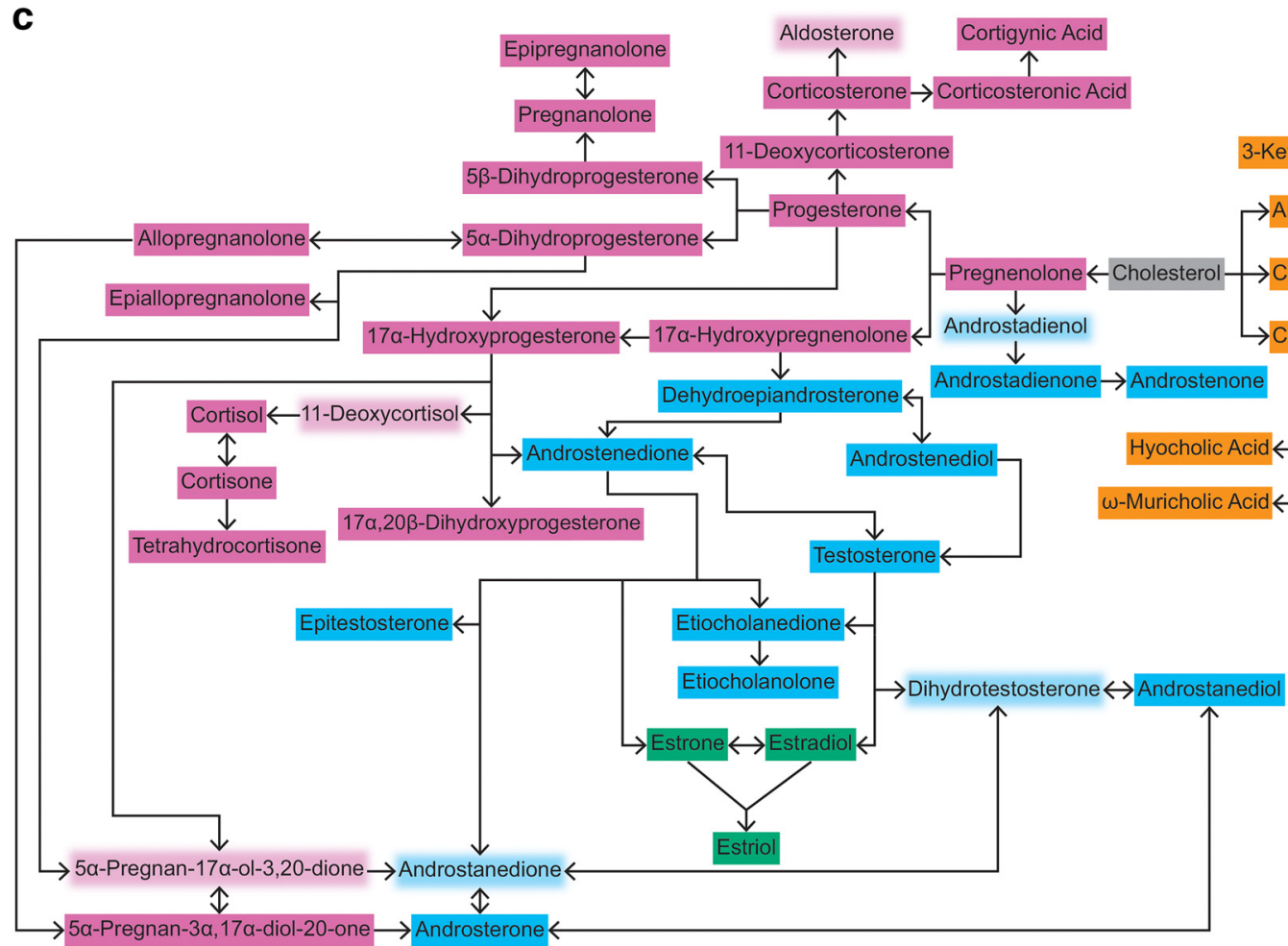

Figure 1. Steroid olfactory cues. $\boldsymbol{a}$, Steroid nucleus structure. Carbons are indicated by numbers and rings by letters. $\boldsymbol{b}$, Steroid classes. The number in parentheses indicates the number of carbon atoms present in each class. $\boldsymbol{c}$, Simplified diagram of steroid biosynthesis. Steroids that have been identified as vertebrate olfactory cues have solid backgrounds. Some intermediate steroids are omitted for clarity. Arrows indicate the proposed directions of synthesis. Reversals and alternative methods are possible. Colors are the same as in $\boldsymbol{b}$.

or bent (trans or $\beta$ ) conformation based on the orientation of a hydrogen at the fifth carbon (Fig. 1a) (Hagey et al., 2010b; Kasal, 2010). An important location of structural diversity among steroids is at the 17th carbon, where side chains of varying lengths are attached (Fig. 1b) (Henley et al., 2005; Kasal, 2010). In general, the number of carbon atoms is used to classify steroids. Cholestanes, like cholesterol, contain 27 carbons. Cholanes, such as the bile acid cholic acid, have 24 carbons. Pregnanes, such as hydrocortisone and progesterone, have 21 carbons. Androstanes, including the predominant male sex steroid testosterone, have 19 carbons but lack a side chain at carbon 17. Androstanes are further metabolized to 18-carbon estrane, for example, the female sex steroid estrogen (Fig. 1b) (Henley et al., 2005; Kasal, 2010; Miller and Auchus, 2011).

Steroids have well-known functional roles in the body, including sexual development (sex steroids), food digestion (bile acids), stress responses (glucocorticoids), and brain function (neurosteroids) (Henley et al., 2005; Kasal, 2010; Miller and Auchus, 2011). Steroids are typically detected in the body through binding to nuclear receptors (for review, see Evans and Mangelsdorf, 2014) or plasma membrane receptors (for review, see Wang et al., 2014). The different functional roles of steroids in the body tend to be associated with the number of carbons and stereochemistry of the molecule. For example, estranes are enriched for estrogens that regulate the ovarian cycle (Henley et al., 2005; Do Rego et al., 2009; Kasal, 2010; Finco et al., 2015).

Because of their potent biological activity, there is tight regulation of steroid synthesis, modification, and excretion. The addition of conjugate groups, such as sulfate, glucuronidate, or taurine, supports steroid mobilization and excretion (Russell, 2003; Fraser et al., 2010; Hofmann et al., 2010; Holder et al., 2010; Miller and Auchus, 2011). Steroid conjugation is most common at free hydroxyl groups, typically those on the third or 17th carbon of the steroid nucleus (Holder et al., 2010; Sjövall et al., 2010). For example, in cholane bile acids, taurine and glycine conjugation is most common at the carboxyl group at the end of the side chain (Hagey et al., 2010a; Hofmann et al., 2010; Sjövall et al., 2010). Conjugation increases water solubility and, in many cases, allows the molecules to be excreted via urine and/or feces. Conjugation can also modify steroid biological activity. For example, neurosteroids, including pregnanes and certain androstanes, are potent modulators of GABA receptors in the brain and have greater biological activity after the addition of a sulfate moiety (Paul and Purdy, 1992; Do Rego et al., 2009; Miller and Auchus, 2011). Excreted steroids are remarkably stable (Stroud et al., 2007). This environmental stability allows excreted steroids to be detected by 

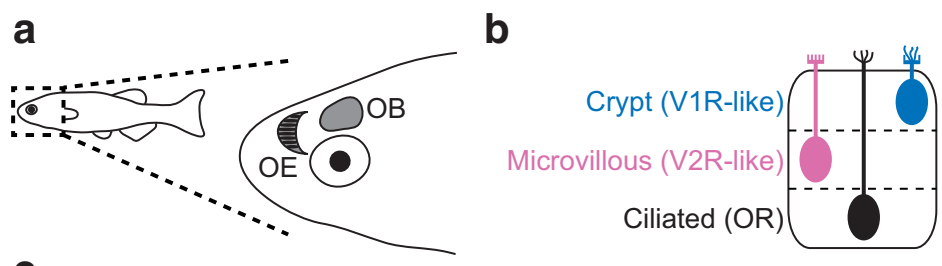

C

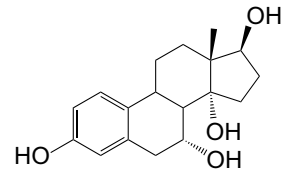

Petromyzestrosterol

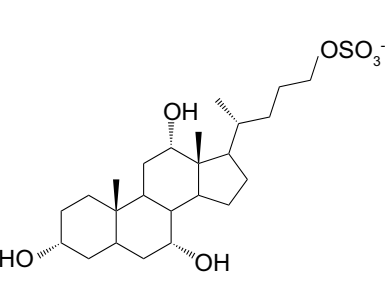

Petromyzonol Sulfate

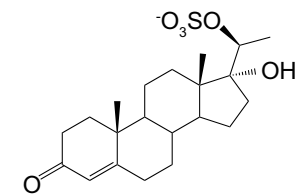

Sulfate

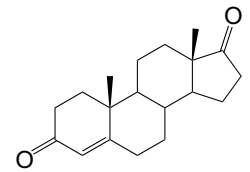

Androstenedione

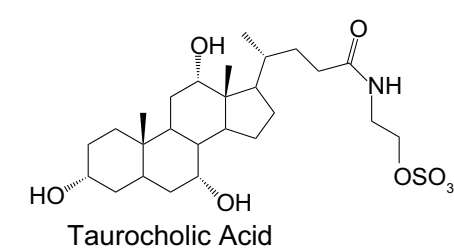

Figure 2. Olfactory steroid detection in bony fish. $\boldsymbol{a}$, Early olfactory system anatomy of bony fish (teleosts). Steroids are detected by sensory neurons in the olfactory epithelia (OE) and are initially processed in the olfactory bulb (OB). $\boldsymbol{b}$, Anatomy of the teleost olfactory epithelium. Teleost sensory neurons include neurons with cilia or microvilli. Crypt cells consist of ciliated and microvillar subpopulations. The steroid-sensing neuronal populations in lampreys (which have only ciliated sensory neurons) and elasmobranchs (which lack ciliated sensory neurons) differ considerably. c, Selected fish steroid olfactory cues. Petromyzestrosterol is a lamprey-specific estrane. $17 \alpha, 20 \beta$-Dihydroxyprogesterone sulfate (also known as 17 $\alpha$,20 $\beta$-dihydroxy-4-pregnen-3-one 20sulfate) is a pregnane that guides mating in goldfish. Androstenedione is an androstane that regulates aggression in goldfish. Petromyzonol sulfate is a bile alcohol that acts as a migratory pheromone in lamprey. Taurocholic acid is a bile acid that is a common vertebrate olfactory cue.

transmembrane receptors expressed in olfactory tissues and be used as chemosignals that reveal information about the status of the emitter to the outside world.

\section{Fishes use excreted steroids as pheromones}

Fish are the earliest evolving vertebrates and include jawless, cartilaginous, and bony fishes (Brazeau and Friedman, 2015). Fish live in water and in low-visibility environments and are especially reliant on water-soluble chemical cues to guide reproductive behavior. Jawless fish (e.g., lampreys and hagfishes), evolved before jawed cartilaginous fish (elasmobranchs; e.g., sharks and rays), which evolved before bony fish (teleosts; e.g., goldfish and salmon) (Huertas et al., 2010; Bazáes et al., 2013; Brazeau and Friedman, 2015). Work in fish olfactory systems has confirmed sensitivity to environmental steroids, leading to the belief that most, if not all, fishes use steroids for chemical communication (Bazáes et al., 2013). The majority of this research has focused on lampreys and teleosts.

In lampreys, excreted steroids have been directly linked to migration and reproduction (W. Li et al., 1995, 2002; Robinson et al., 2009). In their larval phase, lampreys feed on detritus in streambeds, then as adults migrate downstream to feed on other fish. Near the end of their adulthood, lampreys migrate upstream to mate (Buchinger et al., 2015). Unlike migratory species, such as salmon, which learn the chemical composition of their birthplace and return to it in adulthood, lampreys migrate to wherever fed larvae are present (Bett and Hinch, 2016). Fed larvae excrete large amounts of sulfated bile alcohols that attract adults (W. Li et al., 1995; Vrieze and Sorensen, 2001; Fine et al., 2004; Fine and Sorensen, 2008; Yun et al., 2011; Buchinger et al., 2013, 2015).
Several bile alcohols, many of which contain the prefix "petromyzon" after the lamprey taxonomic order "Petromyzontiformes," act in a blend to promote adult migration. The active lamprey steroids include petromyzonol sulfate, petromyzonamine disulfate, petromyzestrosterol, petromyzosterol disulfate, petromyzones, petromyzenes, and allocholic acid (W. Li et al., 1995; W. Li and Sorensen, 1997; Sorensen et al., 2005b; K. Li et al., 2012, 2013a, 2017a,b; Johnson et al., 2014). These steroid ligands are active at nanomolar to subnanomolar concentrations, which is important because these pheromones must diffuse through large volumes of turbid water before reaching their targets (W. Li et al., 1995; K. Li et al., 2012).

Excreted steroids also guide lamprey mating behaviors. Males release a blend of bile alcohols (along with additional unidentified compounds), which potently attract females. Males secrete oxidized forms of the same bile alcohols released by larvae, including 3-ketopetromyzonol sulfate and 3-ketoallocholic acid (Johnson et al., 2009; Buchinger et al., 2013, 2015). Other components of the male pheromone blend include diketo petromyzonene sulfate and an unconjugated estrane petromyzestrosterol ( $\mathrm{K}$. Li et al., 2012, 2013b; Buchinger et al., 2015; Brant et al., 2016). The observation that male lampreys release oxidized versions of larval migratory pheromones seems to indicate that they have coopted larval signals for the purpose of attracting mates (Buchinger et al., 2013). The pheromone activity of petromyzestrosterol and other nonbile alcohol steroids further demonstrates that the lamprey olfactory system can discriminate between members of multiple steroid classes.

The molecular and cellular mechanisms underlying steroid detection by lampreys are not fully understood. Lampreys possess both a main olfactory epithelium and an accessory olfactory organ (not to be confused with the vomeronasal organ found in amphibians and mammals; Fig. 2) (Chang et al., 2013; Buchinger et al., 2015; Daghfous et al., 2016). Neuroepithelial cells in both sensory tissues have ciliated dendrites and express receptors that are related to the olfactory receptor (OR), trace amine-associated receptor (TAAR), and vomeronasal Type I receptor (V1R) families (Grus and Zhang, 2009; Buchinger et al., 2015). Although it is currently unknown which lamprey receptors respond to steroids, there are indications that a specific subpopulation of receptors is involved. The lamprey medial olfactory bulb, which receives dense projections from the accessory olfactory organ, responds most strongly to steroids (Green et al., 2017). However, the medial olfactory bulb does receive a minority of its innervation from the main olfactory epithelium, and steroids also activate the lateral olfactory bulb; so the steroid sensing receptors remain unclear. However, these data do demonstrate that neurons in the accessory olfactory organ are steroid detectors (Chang et al., 2013; Buchinger et al., 2015; Green et al., 2017).

Steroid detection has been confirmed in elasmobranchs, which can detect common cholestane bile acids found in all ver- 
tebrates. Confirmed ligands in sharks and rays include cholic, conjugated chenodeoxycholic, and conjugated lithocholic acid (Meredith et al., 2012). Cholic acid and chenodeoxycholic acid are produced in the liver (so-called primary bile acids), whereas lithocholic acid is a secondary bile acid produced by anaerobic bacteria in the gut (Russell, 2003). Sensitivity to bile acids was observed in the micromolar to nanomolar range, a concentration range similar to other species, indicating that a population of bile acid-sensitive receptors is maintained and/or refined in elasmobranch evolution (W. Li et al., 1995; Michel and Lubomudrov, 1995; Meredith et al., 2012; Doyle et al., 2016). It may be the case that bile acid-responsive receptors in sharks are most sensitive to other naturally secreted steroids other than those currently tested. For example, shark bile is enriched for a sulfated bile alcohol named scymnol sulfate (Hagey et al., 2010b), but more work is needed to determine whether this molecule is a natural ligand with behavioral significance. As in lampreys, the steroid-sensitive neurons and receptors in elasmobranchs remain unclear.

In both lampreys and elasmobranchs, the majority of identified steroid ligands are bile acids and their conjugate salts (W. Li et al., 1995; Siefkes and Li, 2004, 2005; Meredith et al., 2012; Buchinger et al., 2014). Bile salt detection is maintained in teleosts, with responses observed in multiple species (Døving et al., 1980; Hellstrøm and Døving, 1986; Quinn and Hara, 1986; Morin and Døving, 1992; Sola and Tosi, 1993; Michel and Derbidge, 1997; Friedrich and Korsching, 1998; Hara and Zhang, 1998; Zhang et al., 2001; Frade, 2002; Baker et al., 2006; Giaquinto and Hara, 2008; Velez et al., 2009; Zhang and Hara, 2009; Huertas et al., 2010). In addition to bile salt responses, many have noted olfactory sensitivity to steroid hormones in teleosts, such as salmon, trout, and goby (Moore and Scott, 1991, 1992; Essington and Sorensen, 1996; Lastein et al., 2006; Colombo et al., 2009). This has been most deeply studied in Carassius auratus, the common goldfish. In goldfish, increased levels of a pregnane, $17,20 \alpha$, $20 \beta$-dihydroxy-4-pregnen-3-one (also called 17,20 $\beta$-dihydroxyprogesterone), promote oocyte maturation (Van der Kraak et al., 1989). Both conjugated and unconjugated forms of this steroid are released by ovulating females and are detected by male goldfish at nanomolar concentrations (Sorensen et al., 1987, 1995; Poling et al., 2001). These molecules induce courtship behaviors in males, such as chasing and nudging, confirming its action as a pheromone (Poling et al., 2001). An unconjugated androstane, androstenedione, is both produced and detected by mature males and has been shown to promote aggression (Poling et al., 2001; Sorensen et al., 2005a). Zebrafish (Danio rerio) also show strong olfactory responses to conjugated and unconjugated sex hormones. Zebrafish olfactory systems respond to pregnanes, including $17 \alpha, 20 \beta$-dihydroxy-4-pregnen-3-one 20-sulfate, and glucuronidated androstanes and estranes (Hurk and Lambert, 1983; Michel and Lubomudrov, 1995; Friedrich and Korsching, 1998). The round goby (Neogobius melanostomus) and African cichlid (Haplochromis burtoni) also respond to steroid hormones (Robison et al., 1998; Murphy et al., 2001; Cole and Stacey, 2006). The diverse steroid sensitivities observed in multiple teleost species indicate that these fish evolved highly specialized sets of steroid chemoreceptors.

The teleost olfactory epithelium possesses three well-studied populations of sensory neurons: ciliated, microvillar, and crypt cells (Bazáes et al., 2013; Kermen et al., 2013). Rarer cell populations have recently been identified but have not been linked to steroid detection (Ahuja et al., 2014; Wakisaka et al., 2017). Ciliated sensory neurons are located basally and their dendrites are long, whereas microvillar cells are located apically and have shorter dendrites. Crypt cells are located superficially and have a short sensory dendrite (Bazáes et al., 2013; Kermen et al., 2013). As is the case in lamprey, teleost steroid responses are enriched in the medial olfactory bulb, which is innervated by both ciliated sensory neurons and crypt cells (Friedrich and Korsching, 1998; Hansen et al., 2003; Laberge and Hara, 2004; Rolen and Caprio, 2007; Yaksi et al., 2009; Ahuja et al., 2013; Bazáes et al., 2013). It is hypothesized that ciliated sensory neurons respond to bile acids, but the neuronal population responsible for sex steroid detection remains unclear (Thommesen, 1983; Bazáes et al., 2013). Sex steroid responses have been reported in crypt cells, but some studies found only amino acid responses (Vielma et al., 2008; Hamdani el et al., 2008; Bazáes and Schmachtenberg, 2012). Intriguingly, in some species, the number of crypt cells fluctuates throughout the year, with increases seen during the mating season (Hamdani el et al., 2008; Bazáes et al., 2013). In other species, crypt cells expand in number and/or change their preferred ligands following the transition to adulthood, suggesting that the repertoire of putative steroid-detecting neurons may be plastic throughout the life cycle (Bazáes and Schmachtenberg, 2012). Although the receptors responsible for detecting sex steroids in teleosts remain unknown, ciliated sensory neurons are known to express ORs and crypt cells express a V1R-like receptor, indicating that at least one of these receptor families may detect environmental steroid pheromones (Oka et al., 2012; Bazáes et al., 2013; Kermen et al., 2013).

\section{Sulfated steroids are potent olfactory cues in larval amphibians}

Amphibians transition from a purely aquatic larval phase to a mixed aquatic and terrestrial adulthood (Hansen et al., 1998; Dittrich et al., 2016). The olfactory systems of Xenopus frogs (X. tropicalis and $X$. laevis) have been particularly well studied, particularly during the aquatic larval phase (tadpoles; Fig. 3). Xenopus tadpoles contain two olfactory cavities, the principal cavity and vomeronasal organ, both of which are exposed to water-borne odorants (Hansen et al., 1998; Belanger and Corkum, 2009; Dittrich et al., 2016). The tadpole principal cavity contains both ciliated and microvillar sensory neurons, whereas the vomeronasal organ contains only microvillar neurons (Belanger and Corkum, 2009; Dittrich et al., 2016). Bile salts activate the tadpole principal cavity, potentially activating both ciliated and microvillar sensory neurons (Gliem et al., 2013). Although the bile salt sensitivity of the tadpole principal cavity is clear, these molecules were delivered as blends, leaving in question the specific activities of each component molecule and its receptor(s) (Gliem et al., 2013). Both the principal cavity and the vomeronasal organ respond to sulfated pregnanes and estranes, including $17 \beta$ estradiol sulfate (Sansone et al., 2015). 17 $\beta$-Estradiol sulfate is also a potent olfactory cue in the teleost $H$. burtoni, suggesting a conserved capacity for detecting this important sex steroid (Robison et al., 1998; Cole and Stacey, 2006). The 17 $\beta$-estradiol sulfate receptor(s) in both species remain unclear. V2Rs are the only class of receptors known to be expressed in both the principal cavity and the vomeronasal organ in amphibians (Syed et al., 2013, 2017; Sansone et al., 2015). V2Rs in both sensory organs may be the $17 \beta$-estradiol sulfate receptors, but it is also possible that receptors from multiple receptor classes are sensitive to this ligand.

During amphibian metamorphosis, a third cavity develops, called the middle cavity, while the principal cavity is remodeled (Hansen et al., 1998; Dittrich et al., 2016). In adulthood, the newly restructured principal cavity acts a detector for airborne 


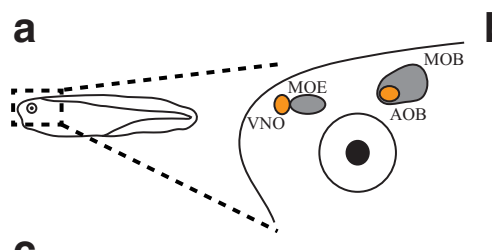

b

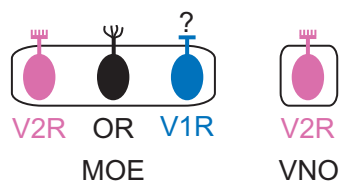

C

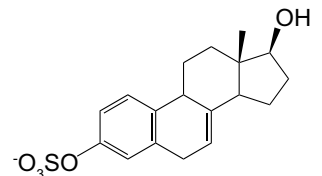

$17 \beta$-Dihydroequilin Sulfate

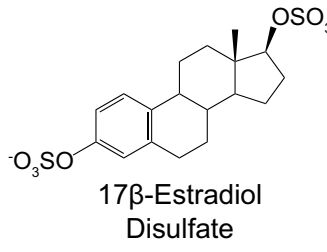

Disulfate
Distradiol

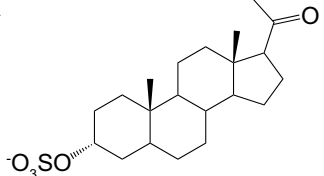

Allopregnanolone Sulfate

Figure 3. Olfactory steroid detection in amphibians. $\boldsymbol{a}$, Early olfactory system anatomy of Xenopus tadpoles. Premetamorphic larva detect odorants through the main olfactory epithelium (MOE) in the principal cavity and in the vomeronasal organ (VNO). Sensory neurons in the MOE project to the main olfactory bulb (MOB), and in the VNO to the AOB. During metamorphosis, the middle cavity housing a third olfactory epithelium develops. $\boldsymbol{b}$, Anatomy of the tadpole olfactory epithelial neurons. V2Rs are expressed in microvillar and ORs in ciliated cells. In tadpoles, it is unknown which cells express V1Rs, although in adults it is in ciliated sensory neurons. c, Example sulfated estranes and pregnanes that activate the tadpole olfactory system. $17 \beta$ dihydroequilin and $17 \beta$-estradiol are sulfated estranes, and allopregnanolone is a sulfated pregnane. These cues also activate the vomeronasal organ of the mouse.

odorants, whereas the middle cavity and vomeronasal organ continue to detect aqueous-phase cues (Hansen et al., 1998). The adult frog vomeronasal organ contains microvillar sensory neurons, whereas the middle cavity and premetamorphic principal cavity contain both ciliated and microvillar sensory neurons (Hansen et al., 1998). The adult principal cavity only contains ciliated sensory neurons (Dittrich et al., 2016). In adult frogs, the anatomical segregation in the nose is maintained in the olfactory bulb. The adult main olfactory bulb is innervated by the principal and middle cavities and the accessory olfactory bulb (AOB) is innervated by the vomeronasal organ (Belanger and Corkum, 2009). Even though receptor composition within the sensory organs is different from amphibians, anatomical segregation of parallel chemosensory streams is conserved in some terrestrial mammals and is thought to reflect specialization of neural pathways that are used to guide innate and learned behaviors (Stowers and Kuo, 2015). The steroid sensitivity of the adult frog olfactory systems has not been studied in depth, but recent work in mammals has revealed a conserved olfactory capacity to detect steroid ligands (Nodari et al., 2008; Isogai et al., 2011; Haga-Yamanaka et al., 2014; Doyle et al., 2016).

\section{Steroids are potent regulators of mating in mammals}

Most terrestrial mammals have two major olfactory subsystems: the main olfactory system and accessory olfactory system (AOS; Fig. 4) (Stowers and Kuo, 2015). In mice, the main olfactory system detects airborne volatile odorants and consists of a main olfactory epithelium with ciliated sensory neurons that innervates the main olfactory bulb (Dulac and Wagner, 2006). The AOS detects aqueous-phase odorants in the vomeronasal organ via microvillar sensory neurons and projects to the AOB (Dulac and Wagner, 2006). This anatomical segregation in the olfactory bulb is reminiscent of the adult frog and indicates a conserved aspect of parallelized olfactory processing in the brain (Belanger and Corkum, 2009).

Recent studies in mice have revealed that several classes of steroids activate neurons of the AOS. Initial studies identified sulfated pregnanes, androstanes, estranes, and glucocorticoids as mouse vomeronasal sensory neuron ligands (Nodari et al., 2008;
Meeks et al., 2010; Isogai et al., 2011; Celsi et al., 2012; Turaga and Holy, 2012; Hammen et al., 2014). These ligands are quite potent, and the neuronal responses demonstrate highly specific steroid tuning profiles (Nodari et al., 2008; Meeks et al., 2010; Turaga and Holy, 2012; Fu et al., 2015; Haga-Yamanaka et al., 2015), but it remains unknown how many of these active steroids are naturally occurring ligands. However, several steroid cues have been identified in relevant biological excretions. The first such molecules were two sulfated glucocorticoids, corticosterone sulfate and cortisol sulfate, which were identified in mouse urine (Nodari et al., 2008). Subsequent research has shown that mice can also detect glucocorticoids with a modified carboxylic acid side chain (Fu et al., 2015), making them structurally similar to bile acids. Sulfated glucocorticoids are upregulated in urine in response to stress, and their detection suggests a neural mechanism by which mammals can evaluate a nearby animal's stress from urinary cues (Nodari et al., 2008). The behavioral relevance of the capacity to detect glucocorticoids is not yet fully understood, but it is noteworthy that sulfated estranes ( $17 \beta$-estradiol sulfate) and glucocorticoid acids (cortigynic and corticosteronic acids) have been implicated in guiding male mating behaviors (Haga-Yamanaka et al., 2014; Fu et al., 2015).

Recent work from our laboratory has shown that unconjugated bile acids, well-known steroid ligands in fishes and amphibians, are present in mouse feces and are potent activators of the mouse AOS. The primary bile acids cholic and chenodeoxycholic acid and their secondary gut derivatives deoxycholic and lithocholic acid produce robust activity in the AOB (Doyle et al., 2016). $\mathrm{AOB}$ neuronal activity patterns were discriminable for each of the four bile acids and also distinguishable from those elicited by sulfated steroid ligands (Doyle et al., 2016). A bile acid that has high levels in rodent bile, $\omega$-muricholic acid, activated a small number of mouse neurons, indicating that the AOS detects bile acids that are relatively unique to a given taxon (muricholic acid) and those that are present across the animal kingdom (cholic and chenodeoxycholic acid) (Doyle et al., 2016). Similar to fish, these results support the hypothesis that bile acids may convey general information about other animals in the environment. Many active bile acids are present in multiple species, whereas others convey taxon-specific information (Hagey et al., 2010a, b; Hofmann et al., 2010). Our initial experiments focused on unconjugated bile acids, but future experiments will determine the breadth of bile acid tuning (e.g., including common conjugates) in the rodent AOS and their roles in guiding animal behavior.

The majority of identified steroid responses in mice have been in the AOS, which begins in the vomeronasal organ. Vomeronasal sensory neurons are microvillar and express V1Rs, V2Rs, formyl peptide receptors, and nonclassical major histocompatibility complex proteins (Dulac and Axel, 1995; Matsunami and Buck, 1997; Ryba and Tirindelli, 1997; Pantages and Dulac, 2000; Loconto et al., 2003; Dulac and Wagner, 2006; Liberles et al., 2009; Rivière et al., 2009). Several V1R-expressing neurons have been shown to be sensitive to sulfated steroids (Isogai et al., 2011; Haga-Yamanaka et al., 2014), and both sulfated steroids 
and bile acids activate the anterior subregion of the AOB (Meeks et al., 2010; Hammen et al., 2014; Doyle et al., 2016), which is selectively innervated by V1Rexpressing sensory neurons (Belluscio et al., 1999; Rodriguez et al., 1999). These results indicate that V1Rs are likely to be the predominant detector of steroids in the mouse. However, responses to sulfated pregnanes have been observed in the posterior AOB (Hammen et al., 2014), which is innervated by V2R-expressing neurons (Del Punta et al., 2002). This indicates that members of both the V1R and $\mathrm{V} 2 \mathrm{R}$ families may serve as steroid detectors in mice. Additional recent work has revealed that neurons expressing members of the MS4A protein family in the "cul-de-sac" regions of the main olfactory epithelium are sensitive to steroids, indicating that subsets of main olfactory sensory neurons are capable of interpreting airborne environmental steroid cues (Greer et al., 2016).

Other mammals, including pigs and humans, have been shown to respond to unconjugated steroids. The best-known steroid ligands in nonrodents are unconjugated volatile androstanes, which are active in both pigs and humans (Melrose et al., 1971; Dorries et al., 1995; Keller et al., 2007). In pigs, androstenone is present in male pig saliva and induces attraction and mating behaviors in estrous females (Melrose et al., 1971; Dorries et al., 1995). Humans are also able to detect the volatile androstanes androstenone and androstadienone (Keller et al., 2007). For humans, these steroids do not appear to have a set valence. Some individuals report them as having pleasant odor qualities, whereas others find them aversive, which is thought to reflect genetic variations affecting receptor sensitivity in the human population (Wysocki and Beauchamp, 1984; Keller et al., 2007). In both pigs and humans, volatile androstanes are detected by the main olfactory epithelium, demonstrating that responses to steroids do not necessarily require a pathway specialized for nonvolatile ligands (Dorries et al., 1997; Keller et al., 2007). It is unknown what receptors detect the odorants in pigs, but in humans, volatile androstanes are detected by ORs (Keller et al., 2007). MS4a receptors may play a role, but their expression and ligand sensitivities in humans remain to be studied (Greer et al., 2016). The ability of humans to detect environmental steroids shows that vertebrates spanning hundreds of millions of years in evolution have maintained the ability to detect external steroids.

\section{What are the steroid chemosensory receptors?}

Despite a wealth of information about steroids that are detected by chemosensory systems, we still know strikingly little about the relationship between these ligands and their chemosensory receptors. The four major classes of transmembrane chemosensory receptors in fish, amphibians, and mammals are ORs, V1Rs, V2Rs, and TAARs (Buck and Axel, 1991; Dulac and Axel, 1995; Matsunami and Buck, 1997; Ryba and Tirindelli, 1997; Pantages and Dulac, 2000; Liberles and Buck, 2006). Chemosensory receptor genes have undergone rapid evolution and the exact comple- ment of expressed receptors changes not only among orders but also among different species (Emes et al., 2004; Grus and Zhang, 2004; Lane et al., 2004; Grus et al., 2005; Kurzweil et al., 2009; Young et al., 2010). This rapid evolution allows for changes in the binding pockets of receptors, allowing them to bind selectively to molecules that differ by only minor changes in structure (Isogai et al., 2011; Haga-Yamanaka et al., 2014, 2015). The lamprey genome contains multiple ORs and TAAR-like genes, a few V1Rs, and no V2Rs (Grus and Zhang, 2009; Libants et al., 2009). V2Rlike genes appear in cartilaginous fish alongside OR-like, TAARlike, and V1R-like receptors (Grus and Zhang, 2009). In most teleosts, the major receptors are ORs, TAARs, and V2R-like receptors (termed olfc receptors), with only a few V1R-like (ora) receptors (Hussain et al., 2009; Behrens et al., 2014; Saraiva et al., 2015). Xenopus express all of the major chemosensory receptor classes and an expanded V2R repertoire (Mezler et al., 1999; Hagino-Yamagishi et al., 2004; Date-Ito et al., 2008; Syed et al., 2013 , 2017). Mice also express all of the major classes of chemosensory receptors with an expansion of V1Rs (Young et al., 2005; Zhang et al., 2007, 2010).

In some cases, anatomy provides clues about the most likely steroid-sensitive receptor classes. In teleosts, sex steroids may activate crypt cells, which express V1R-like receptors, and bile salts are active in regions of the olfactory bulb that are innervated by OR-expressing neurons (Thommesen, 1983; Hansen et al., 2003; Sato et al., 2005; Oka et al., 2012; Biechl et al., 2017). Teleosts may also detect steroids through noncanonical olfactory receptors; for example, goldfish and zebrafish olfactory epithelia express a group of transmembrane progesterone receptors (Kolmakov et al., 2008). In frogs, steroids activate both the principal cavity and the vomeronasal organ. Both organs express V2Rs, but 
Table 1. Example steroid cues with known effects on social behaviors ${ }^{a}$

\begin{tabular}{|c|c|c|c|c|}
\hline Common name & Chemical name & Structural class & Animals & Behavior \\
\hline Petromyzonamine disulfate & $5 \alpha$-cholestane-7 $\alpha$,24-diol N-(3-aminopropyl)2-pyrrolidinone 7,24-disulfate & Cholestane & Fish & Migration \\
\hline Petromyzosterol disulfate $^{b}$ & (3 $\beta, 12 \alpha, 22 \mathrm{E}, 24 \mathrm{)})$-ergost-22-ene-3,12,24-triol, 12,24-disulfate & Ergostane & Fish & Migration \\
\hline Petromyzonol sulfate & $5 \alpha$-cholan-3 $\alpha, 7 \alpha, 12 \alpha, 24$-tetrol 24-sulfate & Cholane & Fish & Migration \\
\hline 3,12-diketo-4,6-petromyzonene-24-sulfate & 4,6-cholestadien-24-01-3,12-one 24-sulfate & Cholane & Fish & Mating \\
\hline $17 \alpha, 20 \beta$-dihydroxyprogesterone & 4-pregnen-17 $\alpha, 20 \beta$-diol-3-one & Pregnane & Mammal & Mating \\
\hline $17 \alpha, 20 \beta$-dihydroxyprogesterone sulfate & 4-pregnen-17 $\alpha, 20 \beta$-diol-3-one 20 -sulfate & Pregnane & Mammal & Mating \\
\hline Androstenone & $5 \alpha$-androst-16-en-3-one & Androstane & Mammal & Mating \\
\hline Androstenedione & 4-androsten-3,17-dione & Androstane & Fish & Aggression \\
\hline $17 \beta$-estradiol disulfate & 1,3,5(10)-estratrien-3,17 $\beta$-diol 3,17-disulfate & Estrane & Mammal & Mating \\
\hline $17 \beta$-estradiol sulfate & 1,3,5(10)-estratrien-3,17 $\beta$-diol 17-sulfate & Estrane & Mammal & Mating \\
\hline
\end{tabular}

${ }^{a}$ A comprehensive list of all known steroid ligands and citations for these ligands are provided in Tables 1-1 (available at https://doi.org/10.1523/JNEUROSCI.2488-17.2018.t1-1) and 1-2 (available at https://doi.org/10.1523/JNEUROSCI. 2488-17.2018.t1-2)

${ }^{b}$ Petromyzosterol disulfate is an ergostane, structurally similar to a cholestane.

the steroid-sensitive receptors remain unknown (Syed et al., 2013, 2017; Sansone et al., 2015). In mice, sulfated steroids and bile acids potently activate the anterior $\mathrm{AOB}$, consistent with detection by V1R receptors, but sulfated pregnanes strongly activate the V2R-targeted posterior AOB (Meeks et al., 2010; Hammen et al., 2014; Doyle et al., 2016), suggesting that both families may contain steroid receptors (Hammen et al., 2014). Candidate gene approaches to identifying steroid ligand-receptor pairs are starting to bear fruit. For example, recent studies have confirmed the steroid sensitivities of individual receptors, marking the beginning of an important phase of discovery in olfaction. In mice, sulfated estranes are detected by Vmn1r85, Vmn1r89, and Vmn1r237, whereas Vmn1r226 and Vmn1r227 detect sulfated corticosteroids (Isogai et al., 2011; Haga-Yamanaka et al., 2014). Humans detect androstanes through the OR ORD74 (Keller et al., 2007). Overall, candidate receptor approaches have been slow. Recent technical advances in activity-mediated transcriptional profiling will enable major gaps in our knowledge of steroid chemosensation to be filled (Jiang et al., 2015; von der Weid et al., 2015). Such unbiased approaches may help to discover other steroid-sensitive receptors, whether within or outside the known complement of olfactory receptors. Overall, the evidence obtained across vertebrate species indicates that a single receptor class is unlikely to serve as a steroid specialist. Instead, it seems apparent that, throughout evolution, receptors in multiple families have acquired steroid sensitivity.

\section{How does steroid chemosensation influence vertebrate behavior?}

Structurally similar steroids typically serve similar internal functions across vertebrate species (e.g., for estranes, this includes modulating sexual maturation and the ovarian cycle) (Henley et al., 2005). At face value, the detection of excreted derivatives of some steroid classes could provide interpretable signals for recipient animals that guide behavior (Table 1; Tables 1-1, available at https://doi.org/10.1523/JNEUROSCI.2488-17.2018.t1-1; and 1-2, available at https://doi.org/10.1523/JNEUROSCI.2488-17.2018. t1-2). For example, in mice, estranes are released by females and drive courtship by males (Haga-Yamanaka et al., 2014). Similarly, in goldfish, females emit pregnanes that drive male mating behavior (Poling et al., 2001). In these cases, the connection between the physiological role of the steroid for the emitter and the behavioral response it generates in the detector are congruent. However, such a relationship is not always clear. For example, the carboxylated glucocorticoid cortigynic acid, which has unknown internal functions in female mice, is a major driver of male mouse attraction (Fu et al., 2015). Internally, bile acids are used in the digestion of lipids, but these molecules also act as lamprey pheromones, driving female sexual attraction (Buchinger et al., 2013).

In addition to the identification of internal physiological states, vertebrates may use olfactory steroid receptors to determine an animal's taxon. Bile salts are potent olfactory cues across vertebrates that may, in part, support this function. This is seen most clearly with lamprey mating and migration, both of which rely on the detection of lamprey-specific bile alcohols, such as petromyzonol sulfate and 3-ketopetromyzonol sulfate (W. Li et al., 2002; Johnson et al., 2009). In other vertebrates, the bile acid complement is more complex and overlapping (Hagey et al., 2010a, b), but the specific combination of bile acids has been hypothesized to be a "molecular fingerprint" useful for identifying taxon (Hofmann et al., 2010). The biological significance of taxon-identifying steroid cues remains to be fully explored, but it seems likely that the behavioral response to such cues will depend on the identity of the detector. For example, detection of a taxonspecific cue may elicit an attractive response (e.g., migration, mating) in conspecifics, but in other animals could produce different behavioral effects. For example, prey could use steroids released by predators, such as the shark-enriched scymnol sulfate, as avoidance cues. In support of the hypothesis that steroids may provide taxon-specific information, it has been reported that a bile acid enriched in lampreys can be detected by teleosts, although the behavioral relevance of this cue is unknown (Baker et al., 2006).

In addition to roles in identifying mates and other species, steroids may also provide other information about the health of other animals or their diet. The first urinary steroid ligands discovered in mice, for example, were sulfated glucocorticoids that increased in mouse urine after acute stress (Nodari et al., 2008). Excreted bile acids vary with diet and gut flora, potentially providing information about the emitters health and vigor (Chiang, 2004). Determining the biological relevance of these and other verified natural steroid ligands has proven difficult, perhaps because the information in these cues is used for subtle distinctions that are difficult to quantify in laboratory behavioral assays.

The full complement of steroids expressed by prominent model organisms and during fundamental physiological states (age, sex, etc.) is far from complete, but it is becoming apparent that the blend of steroids excreted by an individual provides the 
outside world with a readout of its internal biological state (e.g., a potential "honest" signal). Decoding state and/or identity from complex ligand blends is an intrinsic challenge for all chemosensory sensory pathways. At this time, the computational strategies used by steroid-detecting chemosensory pathways remain largely unexplored. At a fundamental level, however, the complexity of steroid chemosensation suggests that there is no universal rule governing the relationship between a particular steroid cue and (1) the receptor class involved in its detection, (2) the pathway into the brain it activates, or (3) the behavioral response. Unraveling the logic of steroid chemosensation represents a major challenge in neuroscience, and answering the many outstanding questions will fill major gaps in our understanding of vertebrate biology.

\section{Outlook}

Steroid detection by olfactory systems is an important aspect of vertebrate biology and supports the survival and reproduction of species from early diverged fishes to mammals. Decades of research have begun to unravel the roles that steroids play in olfactory-mediated behavior, but more research is needed to understand the molecular mechanisms underlying steroid detection, the logic of steroid-decoding neural circuits, and the complement of steroid-mediated behaviors. The growing evidence that mammalian genomes contain multiple chemosensory steroid receptors raises interesting questions about their potential for modulating mammalian physiology. Understanding the "how" and the "why" of olfactory steroid detection will add new insights into brain evolution, and doing so will improve our capacity to understand how the brain uses environmental cues to guide behavior.

\section{References}

Ahuja G, Ivandic I, Saltürk M, Oka Y, Nadler W, Korsching SI (2013) Zebrafish crypt neurons project to a single, identified mediodorsal glomerulus. Sci Rep 3:2063. CrossRef Medline

Ahuja G, Bozorg Nia S, Zapilko V, Shiriagin V, Kowatschew D, Oka Y, Korsching SI (2014) Kappe neurons, a novel population of olfactory sensory neurons. Sci Rep 4:4037. CrossRef Medline

Baker CF, Carton AG, Fine JM, Sorensen PW (2006) Can bile acids function as a migratory pheromone in banded kokopu, Galaxias fasciatus (Gray)? Ecol Freshwater Fish 15:275-283. CrossRef

Bazáes A, Schmachtenberg O (2012) Odorant tuning of olfactory crypt cells from juvenile and adult rainbow trout. J Exp Biol 215:1740-1748. CrossRef Medline

Bazáes A, Olivares J, Schmachtenberg O (2013) Properties, projections, and tuning of teleost olfactory receptor neurons. J Chem Ecol 39:451-464. CrossRef Medline

Behrens M, Frank O, Rawel H, Ahuja G, Potting C, Hofmann T, Meyerhof W, Korsching S (2014) ORA1, a zebrafish olfactory receptor ancestral to all mammalian V1R genes, recognizes 4-hydroxyphenylacetic acid, a putative reproductive pheromone. J Biol Chem 289:19778-19788. CrossRef Medline

Belanger RM, Corkum LD (2009) Review of aquatic sex pheromones and chemical communication in anurans. J Herpetol 43:184-191. CrossRef

Belluscio L, Koentges G, Axel R, Dulac C (1999) A map of pheromone receptor activation in the mammalian brain. Cell 97:209-220. CrossRef Medline

Bett NN, Hinch SG (2016) Olfactory navigation during spawning migrations: a review and introduction of the hierarchical navigation hypothesis. Biol Rev Camb Philos Soc 91:728-759. CrossRef Medline

Biechl D, Tietje K, Ryu S, Grothe B, Gerlach G, Wullimann MF (2017) Identification of accessory olfactory system and medial amygdala in the zebrafish. Sci Rep 7:44295. CrossRef Medline

Brant CO, Huertas M, Li K, Li W (2016) Mixtures of two bile alcohol sulfates function as a proximity pheromone in sea lamprey. PLoS One 11: e0149508. CrossRef Medline
Brazeau MD, Friedman M (2015) The origin and early phylogenetic history of jawed vertebrates. Nature 520:490-497. CrossRef Medline

Buchinger TJ, Wang H, Li W, Johnson NS (2013) Evidence for a receiver bias underlying female preference for a male mating pheromone in sea lamprey. Proc Biol Sci 280:20131966. CrossRef Medline

Buchinger TJ, Li W, Johnson NS (2014) Bile salts as semiochemicals in fish. Chem Senses 39:647-654. CrossRef Medline

Buchinger TJ, Siefkes MJ, Zielinski BS, Brant CO, Li W (2015) Chemical cues and pheromones in the sea lamprey (Petromyzon marinus). Front Zool 12:32. CrossRef Medline

Buck L, Axel R (1991) A novel multigene family may encode odorant receptors: a molecular basis for odor recognition. Cell 65:175-187. CrossRef Medline

Celsi F, D’Errico A, Menini A (2012) Responses to sulfated steroids of female mouse vomeronasal sensory neurons. Chem Senses 37:849-858. CrossRef Medline

Chang S, Chung-Davidson YW, Libants SV, Nanlohy KG, Kiupel M, Brown CT, Li W (2013) The sea lamprey has a primordial accessory olfactory system. BMC Evol Biol 13:172. CrossRef Medline

Chiang JY (2004) Regulation of bile acid synthesis: pathways, nuclear receptors, and mechanisms. J Hepatol 40:539-551. CrossRef Medline

Cole TB, Stacey NE (2006) Olfactory responses to steroids in an African mouth-brooding cichlid, Haplochromis burtoni (Gunther). J Fish Biol 68: 661-680. CrossRef

Colombo L, Marconato A, Belvedere PC, Friso C (2009) Endocrinology of teleost reproduction: a testicular steroid pheromone in the black goby, Gobius jozoL. Boll Zool 47:355-364. CrossRef

Copple BL, Li T (2016) Pharmacology of bile acid receptors: evolution of bile acids from simple detergents to complex signaling molecules. Pharmacol Res 104:9-21. CrossRef Medline

Daghfous G, Green WW, Alford ST, Zielinski BS, Dubuc R (2016) Sensory activation of command cells for locomotion and modulatory mechanisms: lessons from lampreys. Front Neural Circuits 10:18. CrossRef Medline

Date-Ito A, Ohara H, Ichikawa M, Mori Y, Hagino-Yamagishi K (2008) Xenopus V1R vomeronasal receptor family is expressed in the main olfactory system. Chem Senses 33:339-346. CrossRef Medline

Del Punta K, Puche A, Adams NC, Rodriguez I, Mombaerts P (2002) A divergent pattern of sensory axonal projections is rendered convergent by second-order neurons in the accessory olfactory bulb. Neuron 35:10571066. CrossRef Medline

Dittrich K, Kuttler J, Hassenklöver T, Manzini I (2016) Metamorphic remodeling of the olfactory organ of the African clawed frog, Xenopus laevis. J Comp Neurol 524:986-998. CrossRef Medline

Do Rego JL, Seong JY, Burel D, Leprince J, Luu-The V, Tsutsui K, Tonon MC, Pelletier G, Vaudry H (2009) Neurosteroid biosynthesis: enzymatic pathways and neuroendocrine regulation by neurotransmitters and neuropeptides. Front Neuroendocrinol 30:259-301. CrossRef Medline

Dorries KM, Adkins-Regan E, Halpern BP (1995) Olfactory sensitivity to the pheromone, androstenone, is sexually dimorphic in the pig. Physiol Behav 57:255-259. CrossRef Medline

Dorries KM, Adkins-Regan E, Halpern BP (1997) Sensitivity and behavioral responses to the pheromone androstenone are not mediated by the vomeronasal organ in domestic pigs. Brain Behav Evol 49:53-62. CrossRef Medline

Døving KB, Selset R, Thommesen G (1980) Olfactory sensitivity to bile acids in salmonid fishes. Acta Physiol Scand 108:123-131. CrossRef Medline

Doyle WI, Dinser JA, Cansler HL, Zhang X, Dinh DD, Browder NS, Riddington IM, Meeks JP (2016) Faecal bile acids are natural ligands of the mouse accessory olfactory system. Nat Commun 7:11936. CrossRef Medline

Dulac C, Axel R (1995) A novel family of genes encoding putative pheromone receptors in mammals. Cell 83:195-206. CrossRef Medline

Dulac C, Wagner S (2006) Genetic analysis of brain circuits underlying pheromone signaling. Annu Rev Genet 40:449-467. CrossRef Medline

Emes RD, Beatson SA, Ponting CP, Goodstadt L (2004) Evolution and comparative genomics of odorant- and pheromone-associated genes in rodents. Genome Res 14:591-602. CrossRef Medline

Essington TE, Sorensen PW (1996) Overlapping sensitivities of brook trout and brown trout to putative hormonal pheromones. J Fish Biol 48:10271029. CrossRef

Evans RM, Mangelsdorf DJ (2014) Nuclear receptors, RXR, and the Big Bang. Cell 157:255-266. CrossRef Medline

Ferrero DM, Lemon JK, Fluegge D, Pashkovski SL, Korzan WJ, Datta SR, 
Spehr M, Fendt M, Liberles SD (2011) Detection and avoidance of a carnivore odor by prey. Proc Natl Acad Sci U S A 108:11235-11240. CrossRef Medline

Finco I, LaPensee CR, Krill KT, Hammer GD (2015) Hedgehog signaling and steroidogenesis. Annu Rev Physiol 77:105-129. CrossRef Medline

Fine JM, Sorensen PW (2008) Isolation and biological activity of the multicomponent sea lamprey migratory pheromone. J Chem Ecol 34:12591267. CrossRef Medline

Fine JM, Vrieze LA, Sorensen PW (2004) Evidence that petromyzontid lampreys employ a common migratory pheromone that is partially comprised of bile acids. J Chem Ecol 30:2091-2110. CrossRef Medline

Fleischer J, Breer H, Strotmann J (2009) Mammalian olfactory receptors. Front Cell Neurosci 3:9. CrossRef Medline

Frade P (2002) Olfactory sensitivity of the mozambique tilapia to conspecific odours. J Fish Biol 61:1239-1254. CrossRef

Fraser R, Gower DB, Honour JW, Ingram MC, Kicman AT, Makin HL, Stewart PM (2010) Analysis of corticosteroids. In: Steroid analysis (Makin HL, Gower DB, eds), pp 329-455. Dordrecht, The Netherlands: Springer.

Friedrich RW, Korsching SI (1998) Chemotopic, combinatorial, and noncombinatorial odorant representations in the olfactory bulb revealed using a voltage-sensitive axon tracer. J Neurosci 18:9977-9988. Medline

Fu X, Yan Y, Xu PS, Geerlof-Vidavsky I, Chong W, Gross ML, Holy TE (2015) A molecular code for identity in the vomeronasal system. Cell 163:313-323. CrossRef Medline

Giaquinto PC, Hara TJ (2008) Discrimination of bile acids by the rainbow trout olfactory system: evidence as potential pheromone. Biol Res 41:3342. CrossRef Medline

Gliem S, Syed AS, Sansone A, Kludt E, Tantalaki E, Hassenklöver T, Korsching SI, Manzini I (2013) Bimodal processing of olfactory information in an amphibian nose: odor responses segregate into a medial and a lateral stream. Cell Mol Life Sci 70:1965-1984. CrossRef Medline

Green WW, Boyes K, McFadden C, Daghfous G, Auclair F, Zhang H, Li W, Dubuc R, Zielinski BS (2017) Odorant organization in the olfactory bulb of the sea lamprey. J Exp Biol 220:1350-1359. CrossRef Medline

Greer PL, Bear DM, Lassance JM, Bloom ML, Tsukahara T, Pashkovski SL, Masuda FK, Nowlan AC, Kirchner R, Hoekstra HE, Datta SR (2016) A family of non-GPCR chemosensors defines an alternative logic for mammalian olfaction. Cell 165:1734-1748. CrossRef Medline

Grus WE, Zhang J (2004) Rapid turnover and species-specificity of vomeronasal pheromone receptor genes in mice and rats. Gene 340:303-312. CrossRef Medline

Grus WE, Zhang J (2009) Origin of the genetic components of the vomeronasal system in the common ancestor of all extant vertebrates. Mol Biol Evol 26:407-419. CrossRef Medline

Grus WE, Shi P, Zhang YP, Zhang J (2005) Dramatic variation of the vomeronasal pheromone receptor gene repertoire among five orders of placental and marsupial mammals. Proc Natl Acad Sci U S A 102:5767-5772. CrossRef Medline

Haga-Yamanaka S, Ma L, He J, Qiu Q, Lavis LD, Looger LL, Yu CR (2014) Integrated action of pheromone signals in promoting courtship behavior in male mice. Elife 3:e03025. CrossRef Medline

Haga-Yamanaka S, Ma L, Yu CR (2015) Tuning properties and dynamic range of type 1 vomeronasal receptors. Front Neurosci 9:244. CrossRef Medline

Hagey LR, Vidal N, Hofmann AF, Krasowski MD (2010a) Evolutionary diversity of bile salts in reptiles and mammals, including analysis of ancient human and extinct giant ground sloth coprolites. BMC Evol Biol 10:133. CrossRef Medline

Hagey LR, Møller PR, Hofmann AF, Krasowski MD (2010b) Diversity of bile salts in fish and amphibians: evolution of a complex biochemical pathway. Physiol Biochem Zool 83:308-321. CrossRef Medline

Hagino-Yamagishi K, Moriya K, Kubo H, Wakabayashi Y, Isobe N, Saito S, Ichikawa M, Yazaki K (2004) Expression of vomeronasal receptor genes in Xenopus laevis. J Comp Neurol 472:246-256. CrossRef Medline

Hamdani el H, Lastein S, Gregersen F, Døving KB (2008) Seasonal variations in olfactory sensory neurons-fish sensitivity to sex pheromones explained? Chem Senses 33:119-123. CrossRef Medline

Hammen GF, Turaga D, Holy TE, Meeks JP (2014) Functional organization of glomerular maps in the mouse accessory olfactory bulb. Nat Neurosci 17:953-961. CrossRef Medline

Hansen A, Reiss JO, Gentry CL, Burd GD (1998) Ultrastructure of the olfac- tory organ in the clawed frog, Xenopus laevis, during larval development and metamorphosis. J Comp Neurol 398:273-288. CrossRef Medline

Hansen A, Rolen SH, Anderson K, Morita Y, Caprio J, Finger TE (2003) Correlation between olfactory receptor cell type and function in the channel catfish. J Neurosci 23:9328-9339. Medline

Hara TJ, Zhang C (1998) Topographic bulbar projections and dual neural pathways of the primary olfactory neurons in salmonid fishes. Neuroscience 82:301-313. CrossRef Medline

Hellstrøm T, Døving KB (1986) Chemoreception of taurocholate in anosmic and sham-operated cod, Gadus morhua. Behav Brain Res 21:155-162. CrossRef Medline

Henley DV, Lindzey J, Korach KS (2005) Steroid hormones. In: Endocrinology: basic and clinical principles (Melmed S, Conn PM, eds), pp 49-65. Totowa, NJ: Humana.

Hofmann AF, Hagey LR, Krasowski MD (2010) Bile salts of vertebrates: structural variation and possible evolutionary significance. J Lipid Res 51:226-246. CrossRef Medline

Holder G, Makin HL, Bradlow HL (2010) The measurement of estrogens. In: Steroid analysis (Makin HL, Gower DB, eds), pp 605-742. Dordrecht, The Netherlands: Springer.

Houck LD (2009) Pheromone communication in amphibians and reptiles. Annu Rev Physiol 71:161-176. CrossRef Medline

Huertas M, Hagey L, Hofmann AF, Cerdà J, Canário AV, Hubbard PC (2010) Olfactory sensitivity to bile fluid and bile salts in the European eel (Anguilla anguilla), goldfish (Carassius auratus) and Mozambique tilapia (Oreochromis mossambicus) suggests a 'broad range' sensitivity not confined to those produced by conspecifics alone. J Exp Biol 213:308-317. CrossRef Medline

Hurk R, Lambert JG (1983) Ovarian steroid glucuronides function as sex pheromones for male zebrafish, Brachydanio rerio. Can J Zool 61:23812387. CrossRef

Hussain A, Saraiva LR, Korsching SI (2009) Positive Darwinian selection and the birth of an olfactory receptor clade in teleosts. Proc Natl Acad Sci U S A 106:4313-4318. CrossRef Medline

Isogai Y, Si S, Pont-Lezica L, Tan T, Kapoor V, Murthy VN, Dulac C (2011) Molecular organization of vomeronasal chemoreception. Nature 478: 241-245. CrossRef Medline

Jiang Y, Gong NN, Hu XS, Ni MJ, Pasi R, Matsunami H (2015) Molecular profiling of activated olfactory neurons identifies odorant receptors for odors in vivo. Nat Neurosci 18:1446-1454. CrossRef Medline

Johnson NS, Yun SS, Thompson HT, Brant CO, Li W (2009) A synthesized pheromone induces upstream movement in female sea lamprey and summons them into traps. Proc Natl Acad Sci U S A 106:1021-1026. CrossRef Medline

Johnson NS, Yun SS, Li W (2014) Investigations of novel unsaturated bile salts of male sea lamprey as potential chemical cues. J Chem Ecol 40:11521160. CrossRef Medline

Kasal, A (2010) Structure and Nomenclature of Steroids. Steroid Analysis. (Makin HLJ, Gower DB eds), pp 1-25. Available at https://doi.org/10.1023/b135931_1.

Kawamata Y, Fujii R, Hosoya M, Harada M, Yoshida H, Miwa M, Fukusumi S, Habata Y, Itoh T, Shintani Y, Hinuma S, Fujisawa Y, Fujino M (2003) A G protein-coupled receptor responsive to bile acids. J Biol Chem 278: 9435-9440. CrossRef Medline

Keller A, Zhuang H, Chi Q, Vosshall LB, Matsunami H (2007) Genetic variation in a human odorant receptor alters odour perception. Nature 449: 468-472. CrossRef Medline

Kermen F, Franco LM, Wyatt C, Yaksi E (2013) Neural circuits mediating olfactory-driven behavior in fish. Front Neural Circuits 7:62. CrossRef Medline

Kolmakov NN, Kube M, Reinhardt R, Canario AV (2008) Analysis of the goldfish carassius auratus olfactory epithelium transcriptome reveals the presence of numerous non-olfactory GPCR and putative receptors for progestin pheromones. BMC Genomics 9:429. CrossRef Medline

Korsching S (2009) The molecular evolution of teleost olfactory receptor gene families. Results Probl Cell Differ 47:37-55. CrossRef Medline

Kurzweil VC, Getman M, Green ED, Lane RP (2009) Dynamic evolution of V1R putative pheromone receptors between mus musculus and mus spretus. BMC Genomics 10:74. CrossRef Medline

Laberge F, Hara TJ (2004) Electrophysiological demonstration of independent olfactory receptor types and associated neuronal responses in the 
trout olfactory bulb. Comp Biochem Physiol A Mol Integr Physiol 137: 397-408. CrossRef Medline

Lane RP, Young J, Newman T, Trask BJ (2004) Species specificity in rodent pheromone receptor repertoires. Genome Res 14:603-608. CrossRef Medline

Lastein S, Hamdani el H, Døving KB (2006) Gender distinction in neural discrimination of sex pheromones in the olfactory bulb of crucian carp, Carassius carassius. Chem Senses 31:69-77. CrossRef Medline

Li K, Siefkes MJ, Brant CO, Li W (2012) Isolation and identification of petromyzestrosterol, a polyhydroxysteroid from sexually mature male sea lamprey (Petromyzon marinus L.). Steroids 77:806-810. CrossRef Medline

Li K, Brant CO, Siefkes MJ, Kruckman HG, Li W (2013a) Characterization of a novel bile alcohol sulfate released by sexually mature male sea lamprey (Petromyzon marinus). PLoS One 8:e68157. CrossRef Medline

Li K, Brant CO, Huertas M, Hur SK, Li W (2013b) Petromyzonin, a hexahydrophenanthrene sulfate isolated from the larval sea lamprey (Petromyzon marinus L.). Org Lett 15:5924-5927. CrossRef Medline

Li K, Scott AM, Riedy JJ, Fissette S, Middleton ZE, Li W (2017a) Three novel bile alcohols of mature male sea lamprey (Petromyzon marinus) act as chemical cues for conspecifics. J Chem Ecol 43:543-549. CrossRef Medline

Li K, Scott AM, Brant CO, Fissette SD, Riedy JJ, Hoye TR, Li W (2017b) Bile salt-like dienones having a novel skeleton or a rare substitution pattern function as chemical cues in adult sea lamprey. Org Lett 19:4444-4447. CrossRef Medline

Li W, Sorensen PW (1997) Highly independent olfactory receptor sites for naturally occurring bile acids in the sea lamprey, Petromyzon marinus. J Comp Physiol A Neuroethol Sens Neural Behav Physiol 180:429-438. CrossRef

Li W, Sorensen PW, Gallaher DD (1995) The olfactory system of migratory adult sea lamprey (Petromyzon marinus) is specifically and acutely sensitive to unique bile acids released by conspecific larvae. J Gen Physiol 105:569-587. CrossRef Medline

Li W, Scott AP, Siefkes MJ, Yan H, Liu Q, Yun SS, Gage DA (2002) Bile acid secreted by male sea lamprey that acts as a sex pheromone. Science 296: 138-141. CrossRef Medline

Libants S, Carr K, Wu H, Teeter JH, Chung-Davidson YW, Zhang Z, Wilkerson C, Li W (2009) The sea lamprey petromyzon marinus genome reveals the early origin of several chemosensory receptor families in the vertebrate lineage. BMC Evol Biol 9:180. CrossRef Medline

Liberles SD (2009) Trace amine-associated receptors are olfactory receptors in vertebrates. Ann N Y Acad Sci 1170:168-172. CrossRef Medline

Liberles SD, Buck LB (2006) A second class of chemosensory receptors in the olfactory epithelium. Nature 442:645-650. CrossRef Medline

Liberles SD, Horowitz LF, Kuang D, Contos JJ, Wilson KL, Siltberg-Liberles J, Liberles DA, Buck LB (2009) Formyl peptide receptors are candidate chemosensory receptors in the vomeronasal organ. Proc Natl Acad Sci U S A 106:9842-9847. CrossRef Medline

Loconto J, Papes F, Chang E, Stowers L, Jones EP, Takada T, Kumánovics A, Fischer Lindahl K, Dulac C (2003) Functional expression of murine V2R pheromone receptors involves selective association with the M10 and M1 families of MHC class Ib molecules. Cell 112:607-618. CrossRef Medline

Matsunami H, Buck LB (1997) A multigene family encoding a diverse array of putative pheromone receptors in mammals. Cell 90:775-784. CrossRef Medline

Meeks JP, Arnson HA, Holy TE (2010) Representation and transformation of sensory information in the mouse accessory olfactory system. Nat Neurosci 13:723-730. CrossRef Medline

Melrose DR, Reed HC, Patterson RL (1971) Androgen steroids associated with boar odour as an aid to the detection of oestrus in pig artificial insemination. Br Vet J 127:497-502. CrossRef Medline

Meredith TL, Caprio J, Kajiura SM (2012) Sensitivity and specificity of the olfactory epithelia of two elasmobranch species to bile salts. J Exp Biol 215:2660-2667. CrossRef Medline

Mezler M, Konzelmann S, Freitag J, Rössler P, Breer H (1999) Expression of olfactory receptors during development in Xenopus laevis. J Exp Biol 202: 365-376. Medline

Michel WC, Derbidge DS (1997) Evidence of distinct amino acid and bile salt receptors in the olfactory system of the zebrafish, Danio rerio. Brain Res 764:179-187. CrossRef Medline

Michel WC, Lubomudrov LM (1995) Specificity and sensitivity of the olfac- tory organ of the zebrafish, Danio rerio. J Comp Physiol A Neuroethol Sens Neural Behav Physiol 177:191-199. Medline

Miller WL, Auchus RJ (2011) The molecular biology, biochemistry, and physiology of human steroidogenesis and its disorders. Endocr Rev 32: 81-151. CrossRef Medline

Moore A, Scott AP (1991) Testosterone is a potent odorant in precocious male Atlantic salmon (Salmo salar L.) parr. Philos Trans R Soc B Biol Sci 332:241-244. CrossRef

Moore A, Scott AP (1992) 17 alpha,20 beta-dihydroxy-4-pregnen-3-one 20 -sulphate is a potent odorant in precocious male Atlantic salmon (Salmo salar L.) parr which have been pre-exposed to the urine of ovulated females. Proc Biol Sci 249:205-209. CrossRef Medline

Morin PP, Døving KB (1992) Changes in the olfactory function of Atlantic salmon, Salmo salar, in the course of smoltification. Can J Fisheries Aquatic Sci 49:1704-1713. CrossRef

Murphy CA, Stacey NE, Corkum LD (2001) Putative steroidal pheromones in the round goby, Neogobius melanostomus: olfactory and behavioral responses. J Chem Ecol 27:443-470. CrossRef Medline

Niimura Y (2009) Evolutionary dynamics of olfactory receptor genes in chordates: interaction between environments and genomic contents. Hum Genomics 4:107-118. CrossRef Medline

Nodari F, Hsu FF, Fu X, Holekamp TF, Kao LF, Turk J, Holy TE (2008) Sulfated steroids as natural ligands of mouse pheromone-sensing neurons. J Neurosci 28:6407-6418. CrossRef Medline

Oka Y, Saraiva LR, Korsching SI (2012) Crypt neurons express a single V1Rrelated ora gene. Chem Senses 37:219-227. CrossRef Medline

Pantages E, Dulac C (2000) A novel family of candidate pheromone receptors in mammals. Neuron 28:835-845. CrossRef Medline

Paul SM, Purdy RH (1992) Neuroactive steroids. FASEB J 6:2311-2322. CrossRef Medline

Poling KR, Fraser EJ, Sorensen PW (2001) The three steroidal components of the goldfish preovulatory pheromone signal evoke different behaviors in males. Comp Biochem Physiol B Biochem Mol Biol 129:645-651. CrossRef Medline

Quinn TP, Hara TJ (1986) Sibling recognition and olfactory sensitivity in juvenile Coho salmon (Oncorhynchus kisutch). Can J Zool 64:921-925. CrossRef

Rivière S, Challet L, Fluegge D, Spehr M, Rodriguez I (2009) Formyl peptide receptor-like proteins are a novel family of vomeronasal chemosensors. Nature 459:574-577. CrossRef Medline

Robinson TC, Sorensen PW, Bayer JM, Seelye JG (2009) Olfactory sensitivity of pacific lampreys to lamprey bile acids. Trans Am Fisheries Soc 138:144-152. CrossRef

Robison RR, Fernald RD, Stacey NE (1998) The olfactory system of a cichlid fish responds to steroidal compounds. J Fish Biol 53:226-229. CrossRef

Rodriguez I, Feinstein P, Mombaerts P (1999) Variable patterns of axonal projections of sensory neurons in the mouse vomeronasal system. Cell 97:199-208. CrossRef Medline

Rolen SH, Caprio J (2007) Processing of bile salt odor information by single olfactory bulb neurons in the channel catfish. J Neurophysiol 97:4058 4068. CrossRef Medline

Russell DW (2003) The enzymes, regulation, and genetics of bile acid synthesis. Annu Rev Biochem 72:137-174. CrossRef Medline

Ryba NJ, Tirindelli R (1997) A new multigene family of putative pheromone receptors. Neuron 19:371-379. CrossRef Medline

Sansone A, Hassenklöver T, Offner T, Fu X, Holy TE, Manzini I (2015) Dual processing of sulfated steroids in the olfactory system of an anuran amphibian. Front Cell Neurosci 9:373. CrossRef Medline

Saraiva LR, Ahuja G, Ivandic I, Syed AS, Marioni JC, Korsching SI, Logan DW (2015) Molecular and neuronal homology between the olfactory systems of zebrafish and mouse. Sci Rep 5:11487. CrossRef Medline

Sato Y, Miyasaka N, Yoshihara Y (2005) Mutually exclusive glomerular innervation by two distinct types of olfactory sensory neurons revealed in transgenic zebrafish. J Neurosci 25:4889-4897. CrossRef Medline

Siefkes MJ, Li W (2004) Electrophysiological evidence for detection and discrimination of pheromonal bile acids by the olfactory epithelium of female sea lampreys (Petromyzon marinus). J Comp Physiol A Neuroethol Sens Neural Behav Physiol 190:193-199. CrossRef Medline

Siefkes MJ, Winterstein SR, Li W (2005) Evidence that 3-keto petromyzonol sulphate specifically attracts ovulating female sea lamprey, Petromyzon marinus. Anim Behav 70:1037-1045. CrossRef

Sjövall J, Griffiths WJ, Setchell KD, Mano N, Goto J (2010) Analysis of bile 
acids. In: Steroid analysis (Makin HL, Gower DB, eds), pp 837-966. Dordrecht, The Netherlands: Springer.

Sola C, Tosi L (1993) Bile salts and taurine as chemical stimuli for glass eels, Anguilla anguilla: a behavioural study. Environ Biol Fishes 37:197-204. CrossRef

Sorensen PW, Hara TJ, Stacey NE (1987) Extreme olfactory sensitivity of mature and gonadally-regressed goldfish to a potent steroidal pheromone, $17 \alpha, 20 \beta$-dihydroxy-4-pregnen-3-one. J Comp Physiol A Neuroethol Sens Neural Behav Physiol 160:305-313. CrossRef

Sorensen PW, Scott AP, Stacey NE, Bowdin L (1995) Sulfated 17,20 betadihydroxy-4-pregnen-3-one functions as a potent and specific olfactory stimulant with pheromonal actions in the goldfish. Gen Comp Endocrinol 100:128-142. CrossRef Medline

Sorensen PW, Pinillos M, Scott AP (2005a) Sexually mature male goldfish release large quantities of androstenedione into the water where it functions as a pheromone. Gen Comp Endocrinol 140:164-175. CrossRef Medline

Sorensen PW, Fine JM, Dvornikovs V, Jeffrey CS, Shao F, Wang J, Vrieze LA, Anderson KR, Hoye TR (2005b) Mixture of new sulfated steroids functions as a migratory pheromone in the sea lamprey. Nat Chem Biol 1:324328. CrossRef Medline

Stacey NE, Sorensen PW (1986) 17 $\alpha, 20 \beta$-dihydroxy-4-pregnen-3-one: a steroidal primer pheromone increasing milt volume in the goldfish, Carassius auratus. Can J Zool 64:2412-2417. CrossRef

Stowers L, Kuo TH (2015) Mammalian pheromones: emerging properties and mechanisms of detection. Curr Opin Neurobiol 34:103-109. CrossRef Medline

Stroud LR, Solomon C, Shenassa E, Papandonatos G, Niaura R, Lipsitt LP, Lewinn K, Buka SL (2007) Long-term stability of maternal prenatal steroid hormones from the national collaborative perinatal project: still valid after all these years. Psychoneuroendocrinology 32:140-150. CrossRef Medline

Syed AS, Sansone A, Nadler W, Manzini I, Korsching SI (2013) Ancestral amphibian v2rs are expressed in the main olfactory epithelium. Proc Natl Acad Sci U S A 110:7714-7719. CrossRef Medline

Syed AS, Sansone A, Hassenklöver T, Manzini I, Korsching SI (2017) Coordinated shift of olfactory amino acid responses and V2R expression to an amphibian water nose during metamorphosis. Cell Mol Life Sci 74:17111719. CrossRef Medline

Thommesen G (1983) Morphology, distribution, and specificity of olfactory receptor cells in salmonid fishes. Acta Physiol Scand 117:241-249. CrossRef Medline

Turaga D, Holy TE (2012) Organization of vomeronasal sensory coding revealed by fast volumetric calcium imaging. J Neurosci 32:1612-1621. CrossRef Medline

Van der Kraak G, Sorensen PW, Stacey NE, Dulka JG (1989) Periovulatory female goldfish release three potential pheromones: 17 alpha,20 betadihydroxyprogesterone, 17 alpha,20 beta-dihydroxyprogesterone glucuronide, and 17 alpha-hydroxyprogesterone. Gen Comp Endocrinol 73: 452-457. CrossRef Medline

Velez Z, Hubbard PC, Welham K, Hardege JD, Barata EN, Canário AV (2009) Identification, release and olfactory detection of bile salts in the intestinal fluid of the senegalese sole (Solea senegalensis). J Comp Physiol A Neuroethol Sens Neural Behav Physiol 195:691-698. CrossRef Medline
Vielma A, Ardiles A, Delgado L, Schmachtenberg O (2008) The elusive crypt olfactory receptor neuron: evidence for its stimulation by amino acids and cAMP pathway agonists. J Exp Biol 211:2417-2422. CrossRef Medline

von der Weid B, Rossier D, Lindup M, Tuberosa J, Widmer A, Col JD, Kan C, Carleton A, Rodriguez I (2015) Large-scale transcriptional profiling of chemosensory neurons identifies receptor-ligand pairs in vivo. Nat Neurosci 18:1455-1463. CrossRef Medline

Vrieze LA, Sorensen PW (2001) Laboratory assessment of the role of a larval pheromone and natural stream odor in spawning stream localization by migratory sea lamprey (Petromyzon marinus). Can J Fisheries Aquatic Sci 58:2374-2385. CrossRef

Wakisaka N, Miyasaka N, Koide T, Masuda M, Hiraki-Kajiyama T, Yoshihara Y (2017) An adenosine receptor for olfaction in fish. Curr Biol 27:14371447.e4. CrossRef Medline

Wang C, Liu Y, Cao JM (2014) G protein-coupled receptors: extranuclear mediators for the non-genomic actions of steroids. Int J Mol Sci 15: 15412-15425. CrossRef Medline

Wysocki CJ, Beauchamp GK (1984) Ability to smell androstenone is genetically determined. Proc Natl Acad Sci U S A 81:4899-4902. CrossRef Medline

Yabuki Y, Koide T, Miyasaka N, Wakisaka N, Masuda M, Ohkura M, Nakai J, Tsuge K, Tsuchiya S, Sugimoto Y, Yoshihara Y (2016) Olfactory receptor for prostaglandin F2alpha mediates male fish courtship behavior. Nat Neurosci 19:897-904. CrossRef Medline

Yaksi E, von Saint Paul F, Niessing J, Bundschuh ST, Friedrich RW (2009) Transformation of odor representations in target areas of the olfactory bulb. Nat Neurosci 12:474-482. CrossRef Medline

Young JM, Kambere M, Trask BJ, Lane RP (2005) Divergent V1R repertoires in five species: amplification in rodents, decimation in primates, and a surprisingly small repertoire in dogs. Genome Res 15:231-240. CrossRef Medline

Young JM, Massa HF, Hsu L, Trask BJ (2010) Extreme variability among mammalian V1R gene families. Genome Res 20:10-18. CrossRef Medline

Yun SS, Wildbill AJ, Siefkes MJ, Moser ML, Dittman AH, Corbett SC, Li W, Close DA, MacLatchy DL (2011) Identification of putative migratory pheromones from pacific lamprey (Lampetra tridentata). Can J Fisheries Aquatic Sci 68:2194-2203. CrossRef

Zhang C, Hara TJ (2009) Lake char (Salvelinus namaycush) olfactory neurons are highly sensitive and specific to bile acids. J Comp Physiol A Neuroethol Sens Neural Behav Physiol 195:203-215. CrossRef Medline

Zhang C, Brown SB, Hara TJ (2001) Biochemical and physiological evidence that bile acids produced and released by lake char (Salvelinus namaycush) function as chemical signals. J Comp Physiol B 171:161-171. CrossRef Medline

Zhang J, Pacifico R, Cawley D, Feinstein P, Bozza T (2013) Ultrasensitive detection of amines by a trace amine-associated receptor. J Neurosci 33 : 3228-3239. CrossRef Medline

Zhang X, Zhang X, Firestein S (2007) Comparative genomics of odorant and pheromone receptor genes in rodents. Genomics 89:441-450. CrossRef Medline

Zhang X, Marcucci F, Firestein S (2010) High-throughput microarray detection of vomeronasal receptor gene expression in rodents. Front Neurosci 4:164. CrossRef Medline 